\title{
Pendampingan Bimbingan Belajar Akademik dan Religius di Dukuh Kejambon Kidul, Desa Sindumartani, Kecamatan Ngemplak, Kabupaten Sleman
}

\author{
Nabila Aqidatul Aisyah ${ }^{1}$, Asti Nurvirginawati ${ }^{2}$, Firda Jihan Tianotak ${ }^{3}$, Imas Esti Kurniasih ${ }^{3}$, Riza Kurniawati ${ }^{3}$, Ice Larasati ${ }^{4}$, \\ Defri Fitriya Nengsih ${ }^{4}$, Eva Silvia Ningsih ${ }^{4}$, Fitroh Syuaidah Saryanto ${ }^{4}$, Dina Seftina ${ }^{5}$, Fatma Siti Fatimah ${ }^{4}$, Nila Hidayah ${ }^{1}$ \\ Universitas Alma Ata \\ Email: nabilaaisyah017@gmail.com
}

\section{Received 26 November 2021; Revised - ; Accepted for Publication 29 November 2021; Published 30 November 2021}

\begin{abstract}
Home tutoring assistance is needed during the Covid-19 pandemic, where all schools implement Distance Learning (PJJ) activities. The Ministry of Education and Culture issues regulations so that all learning activities at school are carried out at each student's home. The enactment of the PJJ policy makes parents have the responsibility to assist children while learning from home. In addition, the Covid-19 pandemic has an impact on TPA / $T P Q$ activities at Dukuh Kejambon Kidul. For this reason, through tutoring assistance carried out by UAA 2021 Thematic KKN students as a form of community service, it can help children a total of 21 students, who have difficulty in the learning process at home and re-organize TPA / TPQ activities during the Covid-19 pandemic at the Kejambon Kidul hamlet in particular. RT 04 and 05. The learning methods applied during the morning class activities are lectures, fairy tales, question and answer, and practice. In conclusion can be drawn is that the activities of assisting academic, religious and educational guidance for Covid-19 for children can take place smoothly.
\end{abstract}

Keywords - Tutoring Assistance, TPA / TPQ, Covid-19 Pandemic.

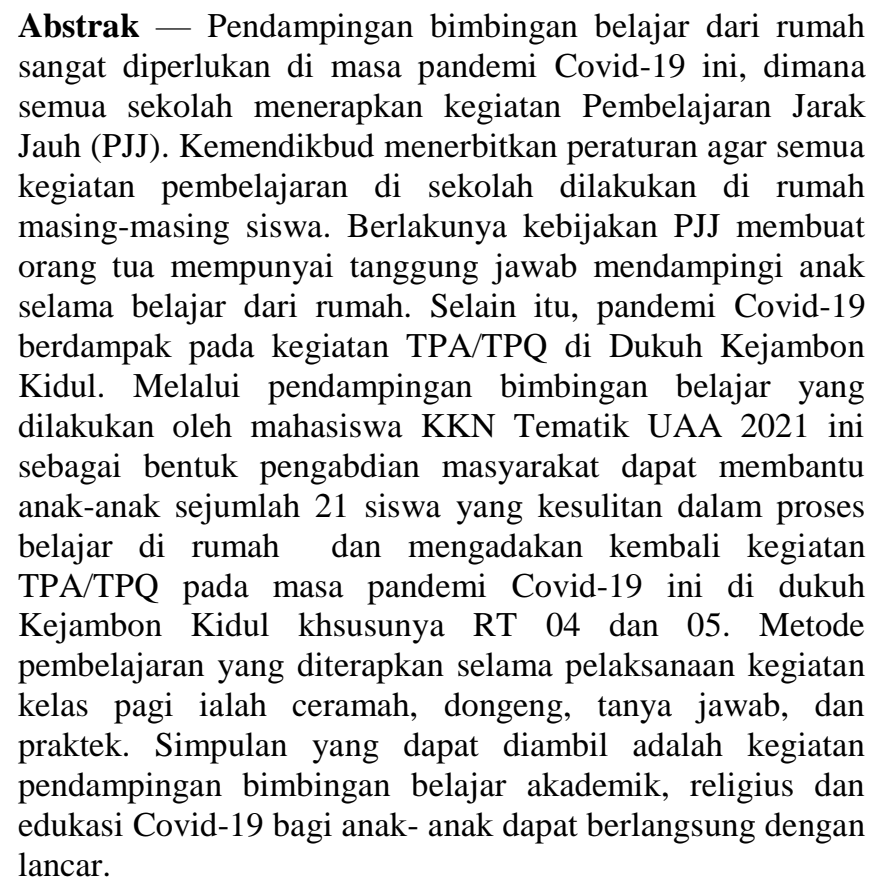

Abstrak - Pendampingan bimbingan belajar dari rumah sangat diperlukan di masa pandemi Covid-19 ini, dimana orang tua mempunyai tanggung jawab mendampingi anak selama belajar dari rumah. Selain itu, pandemi Covid-19 berdampak pada kegiatan TPA/TPQ di Dukuh Kejambon Kidul. Melalui pendampingan bimbingan belajar yang TPA/TPQ pada masa pandemi Covid-19 ini di dukuh Kejambon Kidul khsusunya RT 04 dan 05. Metode pembelajaran yang diterapkan selama pelaksanaan kegiatan kelas pagi ialah ceramah, dongeng, tanya jawab, dan edukasi Covid-19 bagi anak- anak dapat berlangsung dengan lancar.
Kata Kunci - Pendampingan Bimbingan Belajar, TPA/TPQ, Pandemi Covid-19.

\section{PENDAHULUAN}

KKN merupakan wahana pembelajaran mahasiswa di masyarakat. Sarana penting bagi mahasiswa untuk mendapatkan pengalaman secara nyata beriteraksi, belajar, mengajar, mengembangkan dan mengoptimalkan pemberdayaan masyarakat. Langkah nyata keterlibatan masyarakat dalam membangun desa atau lokasi KKN dan memajukan masyarakat harus diimbangi dengan manajemen pengelolaan pelaksanaannya sehingga dapat memberikan dampak perubahan yang berkelanjutan. KKN tematik sebagai realisasi dari kegiatan Merdeka Belajar Kampus Merdeka (MBKM) atau lebih masyhur dengan istilah Kampus Merdeka. Kegiatan ini bertujuan sebagai upaya Perguruan Tinggi (PT) turut bersinergi membantu memperkuat ketahanan kesehatan masyarakat dan wujud pengabdian mahasiswa untuk belajar hidup bermasyarakat.

Dengan adanya pandemi Covid-19 yang terjadi di Indonesia, kegiatan belajar mengajar selama pandemi Covid-19 dilakukan secara daring atau memberlakukan Pembelajaran Jarak Jauh (PJJ) sebagai salah satu upaya pemerintah dalam memutus penyebaran virus Covid-19. Covid-19 adalah penyakit menular yang disebabkan oleh jenis coronavirus yang baru ditemukan. Walaupun lebih banyak menyerang pada lansia, virus ini sebenarnya bisa juga menyerang siapa saja, mulai dari bayi, anak-anak, hingga orang dewasa. Virus corona ini bisa menyebabkan gangguan ringan pada sistem pernapasan, infeksi paru-paru yang berat, hingga kematian [1].

Sejak 1 Juli 2020, pemerintah menetapkan sebuah sistem baru yang diterapkan pasca PSBB, yaitu Adaptasi Kebiasaan Baru [2]. Tatanan kebiasaan baru menjadi upaya menjembatani pembangunan kesehatan dan ekonomi akibat pandemi Covid-19 yang belum dapat diketahui kapan akan berakhir. Sistem pendidikan jarak jauh (PJJ) [3], yang dipersepsikan sebagai inovasi abad 21, merupakan sistem pendidikan yang memiliki daya jangkau luas lintas ruang, waktu, dan sosioekonomi. Sistem PJJ membuka akses terhadap pendidikan bagi siapa saja, di mana saja dan kapan saja. Berdasarkan karakteristik tersebut, sistem PJJ seringkali dianggap sebagai solusi terhadap berbagai masalah pendidikan, terutama yang berkaitan dengan pemerataan dan demokratisasi pendidikan, serta perluasan akses terhadap pendidikan berkualitas kepada seluruh lapisan masyarakat lintas ruang dan waktu [4]. 
Berlakunya kebijakan baru tersebut membuat orang tua mempunyai tanggung jawab mendampingi anak selama belajar dari rumah. Selain itu anak-anak malas belajar karena sudah merasa sulit dalam mengerjakan tugas sehingga tidak perlu untuk dipelajari. Dengan kata lain hal ini mengakibatkan motivasi belajar anak-anak menurun. Salah satu kegiatan yang membantu peserta didik mengembangkan diri dalam meningkatkan kemampuan dalam pembelajaran ialah bimbingan belajar. Bimbingan belajar adalah bimbingan dalam hal menemukan cara belajar yang tepat, dalam memilih program setudi yang sesuai, dan dalam mengatasi kesukaran-kesukaran yang timbul berkaitan dengan tuntunan-tuntunan belajar di suatu institusi pendidikan. Berdasarkan uraian di atas, bimbingan belajar sebagai sarana untuk membantu peserta didik dalam memahami materi pada berbagai mata pelajaran.

\section{METODE PENGABDIAN}

Kegiatan program kerja KKN Tematik UAA Yogyakarta 2021 yang dilakukan di masa pandemi Covid-19 ini salah satunya adalah pendampingan bimbingan belajar dari rumah dengan peserta 21 siswa.

Metode yang digunakan dalam kegiatan ini adalah ceramah dengan cara penjelasan beberapa materi terlebih dahulu terkait kegiatan pembelajaran [5]. Kedua adalah adanya tanya jawab atas materi yang kurang dipahami oleh anak-anak. Kemudian mendiskusikan mengenai materi yang sudah diberikan.

Ada beberapa tahap sebelum kegiatan pendampingan bimbingan belajar dan TPA/TPQ dilaksanakan. Tahap pertama adalah penyiapan kelengkapan administrasi berupa buku presensi. Selanjutnya, mempersiapkan materi-materi pembelajaran peserta didik untuk membantu pendampingan bimbingan belajar. Selain itu juga mempersiapkan waktu pelaksanaan, tempat pelaksanaan dan perlengkapan yang bertujuan untuk sarana agar anak-anak mengikuti kegiatan pendampingan bimbingan belajar dengan baik.

Tahap kedua adalah tahapan pelaksanaan. Pelaksanaan kegiatan pendampingan belajar dilaksanakan dalam bentuk pertemuan tatap muka sesuai dengan waktu dan tempat yang telah ditentukan. Kegiatan pendampingan bimbingan belajar berupa pendampingan anak-anak mengerjakan tugas yang diberikan oleh guru sekolah, penerapan teknik perkalian jari matika untuk jenjang Sekolah Dasar (SD) dan SMP, bimbingan mengaji, menulis huruf hijaiyyah, membuat karya origami sebagai wujud pengembangan keterampilan dan kreatifitas dan beberapa macam bimbingan yang lainnya dengan menerapkan protokol kesehatan yang sesuai dengan aturan.

Tahap ketiga adalah tahapan evaluasi. Pada tahap evaluasi ini dilaksanakan dengan mengadakan kegiatan field trip [6]. Field trip adalah metode penyampaian materi pelajaran dengan cara membawa langsung siswa ke obyek di luar kelas atau di lingkungan yang berdekatan dengan sekolah agar siswa dapat mengamati atau mengalami secara langsung [7]. Kegiatan ini dibagi menjadi tiga pos, pada setiap pos anak-anak yang sudah dibagi menjadi beberapa kelompok kemudian diberi sebuah pertanyaan yang pernah diajarkan selama pendampingan bimbingan belajar berlangsung. Selain belajar anak-anak juga bermain di lingkungan sekitar.

\section{HASIL DAN PEMBAHASAN \\ Tahapan Pelaksanaan Kegiatan}

Program pendampingan bimbingan belajar dilaksanakan setiap hari Senin, Selasa, Rabu, Kamis, Jumat (rentang tanggal 25 Maret - 15 April 2021), dengan sasaran anak-anak usia TK, Sekolah Dasar dan SMP sebanyak 20 anak di lingkungan pedukuhan Kejambon Kidul, Desa Sindumartani, Kecamatan Ngemplak, Kabupaten Sleman.

Dengan metode pendampingan berupa metode ceramah dan diskusi. Metode ini dilaksanakan secara tatap muka sesaui standar Protokol Kesehatan. Anak-anak mengerjakan tugas yang diberikan oleh guru sekolah, penerapan teknik perkalian jari matika untuk jenjang Sekolah Dasar dan SMP, mengajarkan Perilaku Hidup Bersih dan Sehat (PHBS) [8], bimbingan mengaji iqro' dan Al-Quran, menulis huruf hijaiyyah, bimbingan belajar menulis huruf alfabet, angka, doa-doa, serta keterampilan dari origami. Melalui metode ini anak-anak akan lebih mengerti dan menguasai apa yang disampaikan oleh guru pendamping. Penyampaian konsep guru pendamping terhadap anak didik dikemas sebaik mungkin sehingga informasi yang di berikan bisa diterima dengan baik.

Materi yang diberikan oleh anggota KKN antara lain penerapan teknik perkalian jari matika sama seperti Teknik dari diana dkk [9]. Salah satu anggota KKN menyampaikan materi dengan metode ceramah, kemudian peserta pendampingan dibentuk kelompok untuk berdiskusi yang didampingi oleh anggota KKN. Tahap selanjutnya pemberian latihan individu untuk melihat kemampuan peserta pendampingan setelah dilakukan diskusi. Materi lain seperti mengajarkan PHBS, belajar iqra' dan Al-Qur'an, menulis huruf hijaiyyah, menulis huruf alfabet dan angka, berhitung, dan penerapan metode bernyanyi dalam mengenalkan pada pengetahuan agama Islam.

Pendampingan belajar diikuti sebanyak 21 anak jenjang pendidikan Taman Kanak-Kanak (TK), Sekolah Dasar (SD), SMP dan SMA.

Grafik 1 Kepesertaan peserta didik

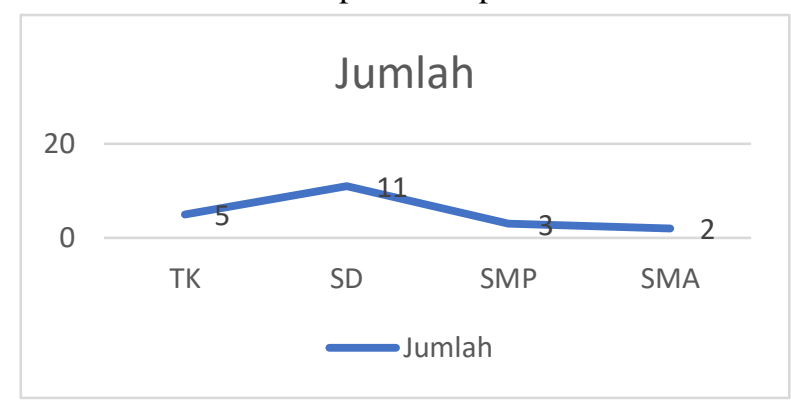


Pendampingan Bimbingan Belajar Akademik dan Religius di Dukuh Kejambon Kidul, Desa Sindumartani, Kecamatan Ngemplak,

Tabel 1. Karakteristik Usia peserta didik

\begin{tabular}{ccc}
\hline NO & $\begin{array}{c}\text { Jenjang } \\
\text { Pendidikan }\end{array}$ & Kelas \\
\hline 1 & TK & - \\
\hline 2 & TK & - \\
\hline 3 & TK & - \\
\hline 4 & TK & - \\
\hline 5 & TK & - \\
\hline 6 & SD & 1 \\
\hline 7 & SD & 1 \\
\hline 8 & SD & 2 \\
\hline 9 & SD & 2 \\
\hline 10 & SD & 3 \\
\hline 11 & SD & 3 \\
\hline 12 & SD & 4 \\
\hline 13 & SD & 4 \\
\hline 14 & SD & 4 \\
\hline 15 & SD & 4 \\
\hline 16 & SD & 5 \\
\hline 17 & SMP & 7 \\
\hline 18 & SMP & 8 \\
\hline 19 & SMP & 9 \\
\hline 20 & SMA & 10 \\
\hline 21 & SMA & 10 \\
\hline & &
\end{tabular}

Pelaksanaan pendampingan belajar menggunakan metode ceramah dan diskusi secara tatap muka mendorong anak-anak [10] di Kejambon Kidul lebih giat dalam belajar. Dapat dilihat dari interaksi anak-anak dengan pendamping, dimana anak-anak sangat aktif mengikuti kegiatan pembelajaran ketika pendampingan berlangsung. Interaksi berupa komunikasi juga terbentuk dengan baik antara anakanak dengan pendamping dan antar anak-anak yang mengikuti kegiatan pendampingan [11] .

\section{Tahapan Evaluasi}

Pendampingan belajar meningkatkan motivasi belajar [12] di Kejambon Kidul dilaksanakan sebanyak 15 kali pertemuan dan mendapatkan respon yang baik dari anakanak. Semua pertemuan dilaksanakan secara tatap muka dengan menggunakan metode ceramah dan diskusi. Anakanak selalu berminat atau antusias ditandai dengan rasa ingin tahu yang cukup tinggi. Dimana anak bertanya kepada pendamping ketika proses belajar mengajar berlangsung. Selain itu, anak-anak juga mempunyai respon yang tinggi untuk belajar dan terkadang tak menyadari bahwa waktu sudah habis.

Keberhasilan pendampingan bimbingan belajar di rumah bagi anak- anak di Dukuh Kejambon Kidul dapat dilihat dengan terbantunya kegiatan Pembelajaran Jarak Jauh (PJJ) dan antusias anak- anak dalam mengikuti kegiatan pendampingan bimbingan belajar [13] serta dalam menerapkan perilaku hidup bersih dan sehat dalam mencegah penyebaran Covid-19.

Harapan dari dilaksanakan kegiatan ini adalah anakanak menjadi lebih paham dalam menerima materi karena dijelaskan secara langsung dan dapat memahami serta mengerjakan tugas yang diberikan oleh guru mereka.

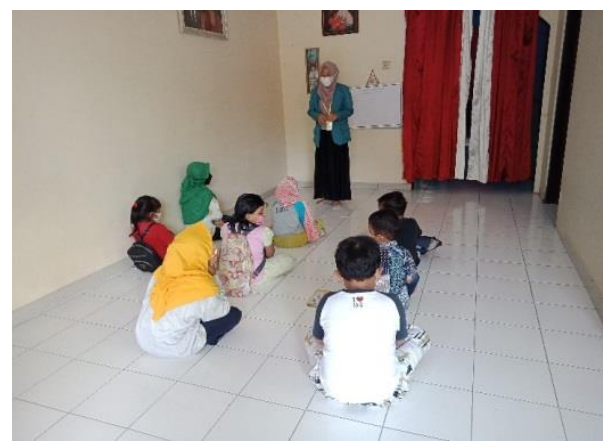

Gambar 1. Bimbingan Belajar

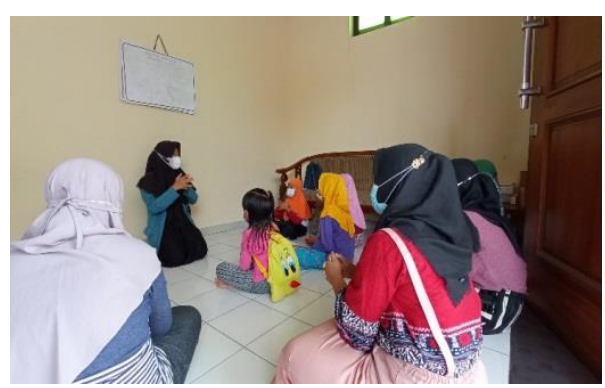

Gambar 2. Perilaku Hidup Bersih dan Sehat (PHBS)

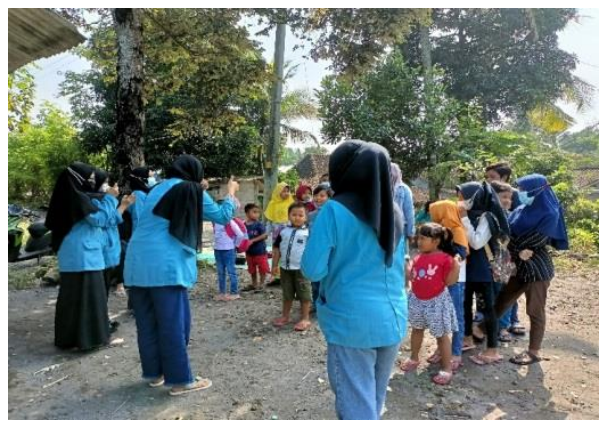

Gambar 3. Field Trip

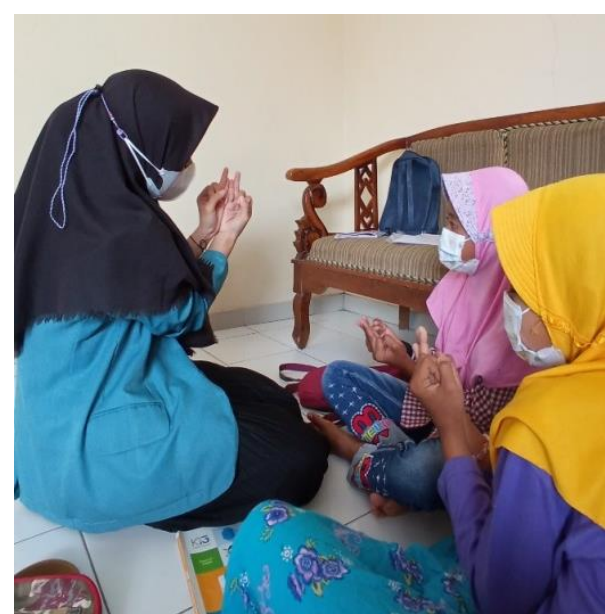

Gambar 4. Teknik Perkalian Jari Matika 


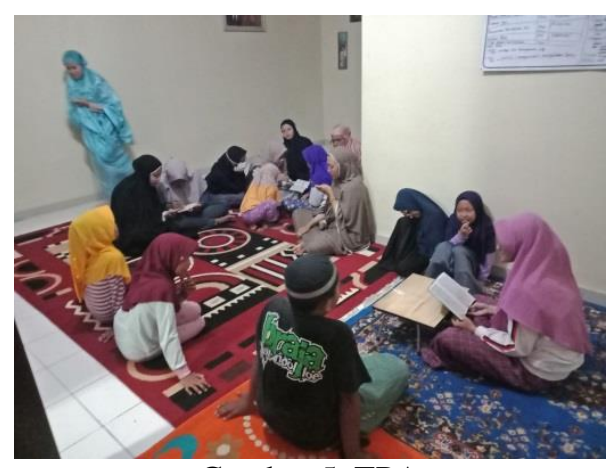

Gambar 5. TPA

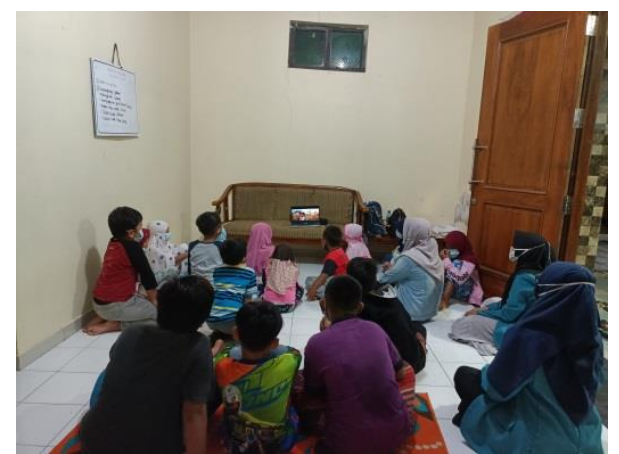

Gambar 6. Menanamkan Nilai Religius dalam Film Animasi Bilal

\section{KESIMPULAN}

Pendampingan bimbingan belajar dilaksanakan di Pedukuhan Kejambon Kidul, Desa Sindumartani, Kecamatan Ngemplak, Kabupaten Sleman. Simpulan yang dapat diambil adalah kegiatan pendampingan bimbingan belajar akademik, religius dan edukasi Covid-19 bagi anakanak dapat berlangsung dengan lancar. Keberhasilan kegiatan ini dapat dilihat dengan terbantunya kegiatan Pembelajaran Jarak Jauh (PJJ) dan antusias anak- anak dalam mengikuti kegiatan pendampingan bimbingan belajar serta dalam menerapkan perilaku hidup bersih dan sehat dalam mencegah penyebaran Covid-19. Pendampingan bimbingan belajar tersebut juga membantu orang tua dan anak-anak dukuh Kejambon Kidul RT 04 dan RT 05 dalam membimbing dan belajar selama Pembelajaran Jarak Jauh (PJJ). Harapan dari dilaksanakan kegiatan ini adalah anakanak menjadi lebih paham dalam menerima materi karena dijelaskan secara langsung dan dapat memahami serta mengerjakan tugas yang diberikan oleh guru mereka.

\section{DAFTAR PUSTAKA}

[1] R. Yektyastuti, L. Nuroniah, and M. Andiani, "Rumah Pintar: Bimbingan Belajar Siswa Sekolah Dasar di Masa Pandemi Covid-19. Educivilia," J. Pengabdi. pada Masy., vol. 2, no. 1, pp. 83-91, 2021.

[2] N. Arafah and S. Bahri, "Peningkatan Human Capital Dalam Proses Pembelajaran di Era New Normal," J. Manaj. Bisnis, vol. 17, no. 3, pp. 425444, 2020.

[3] E. Irawan et al., Pendidikan Tinggi Di Masa
Pandemi: $\quad$ Transformasi, Adaptasi, dan Metamorfosis Menyongsong New Normal. Zahir Publishing, 2020.

[4] F. Septian, "Pelatihan Pendidikan Jarak Jauh (PJJ) Berbantuan Media Sosial Edmodo. com bagi Guru SMP Terbuka Sawangan Depok," JAMAIKA J. Abdi Masy., vol. 1, no. 2, pp. 60-68, 2020.

[5] M. Mahmudah, "Urgensi diantara Dualisme Metode Pembelajaran Ceramah dalam Kegiatan Belajar Mengajar untuk Siswa MI/SD Cakrawala," J. Stud. Islam, vol. 11, no. 1, pp. 116-129, 2016.

[6] K. Nusi, "Penerapan Metode Field Trip dalam meningkatkan Kemampuan Berbicara pada Siswa Kelas V SD INPRES 2 Tanamodindi Palu," BAHASANTODEA, vol. 4, no. 2, 2016.

[7] R. G. Nugraha, "Meningkatkan ecoliteracy siswa SD melalui metode field-trip kegiatan ekonomi pada mata pelajaran ilmu pengetahuan sosial," Mimb. Sekol. Dasar, vol. 2, no. 1, pp. 60-72, 2015.

[8] K. M. Ali and R. Muhammad, "Pendampingan Perilaku Hidup Bersih dan Sehat (PHBS) pada Keluarga di Kelurahan Tobololo Kota Ternate di Era New Normal," ABDIMAS MULAWARMAN J. Pengabdi. Kpd. Masy., pp. 25-31, 2021.

[9] Q. Diana and S. Naiesa, "Pelatihan Teknik Jarimatika Bagi Siswa Mi Wilayah Fatimatuz Zahro Pondok Pesantren Nurul Jadid," 2021.

[10] R. Sanyoto, R. A. Rizky, A. R. Fauzi, A. Wahid, and K. P. Dewi, "Pendampingan Belajar Untuk Menekankan Kematangan Belajar Siswa Pada Masa Pandemi," 2020.

[11] Y. Munica, F. N. Utami, O. K. Saputri, M. Al Fadhil, Y. A. Maulana, and P. K. Nashiroh, "Pendampingan Belajar Siswa Selama Pandemi Covid-19 Melalui Kegiatan Bimbingan Belajar Di Desa Pandansari Kabupaten Banyumas," Daft. Artik., p. 8, 2020.

[12] Darmayanti, N. W. S., I. N. Sueca, L. S. Utami, and N. Sari, "Pendampingan Bimbingan Belajar Di Rumah Bagi Siswa SD Dusun Buruan Tampaksiring Untuk Menumbuhkan Motivasi Belajar Siswa. Selaparang," J. Pengabdi. Masy. Berkemajuan, vol. 3, no. 2, pp. 207-210, 2020.

[13] B. Setiyawan, F. Rafly, V. D. Lestari, M. R. Hasan, and A. Difaulhaq, "Pendampingan Bimbingan Belajar Di Rumah Bagi Anak-Anak Sekolah Di Desa Mijen Kecamatan Kaliwungu Kabupaten Kudus Yang Terdampak Pandemi Covid-19,” 2020. 
Pendampingan Bimbingan Belajar Akademik dan Religius di Dukuh Kejambon Kidul, Desa Sindumartani, Kecamatan Ngemplak,
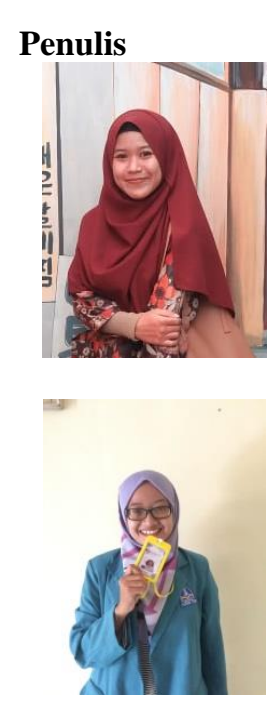

Asti Nurvirginiawati, prodi Pendidikan Guru Sekolah Dasar, Fakultas Keguruan dan Ilmu Pendidikan, Universitas Alma Ata Yogyakarta.

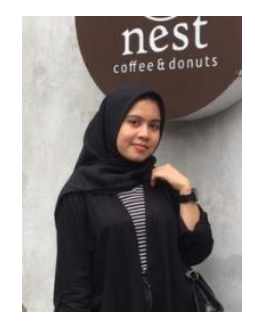

Firda Jihan Tianotak, prodi Farmasi, Fakultas Ilmu-Ilmu Kesehatan, Universitas Alma Ata.

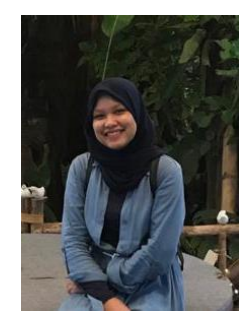

Imas Esti Kurniasih, prodi Farmasi, Fakultas Ilmu-Ilmu Kesehatan, Universitas Alma Ata.

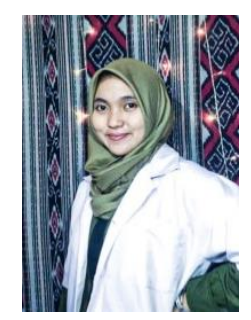

Riza Kurniawati, prodi Farmasi, Fakultas Ilmu-Ilmu Kesehatan, Universitas Alma Ata.

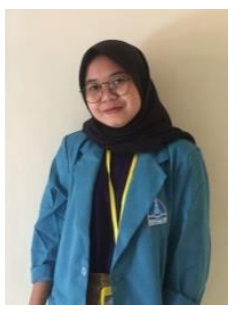

Ice Larasati, Administrasi Rumah Sakit, Fakultas Ilmu-Ilmu Kesehatan, Universitas Alma Ata.
Defri Fitriya Nengsih, prodi Administrasi Rumah Sakit, Fakultas Ilmu-Ilmu Kesehatan, Universitas Alma Ata.

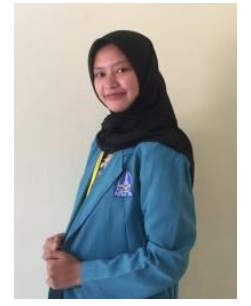

Eva Silvia Ningsih, prodi Administrasi Rumah Sakit, Fakultas Ilmu-Ilmu Kesehatan, Universitas Alma Ata.

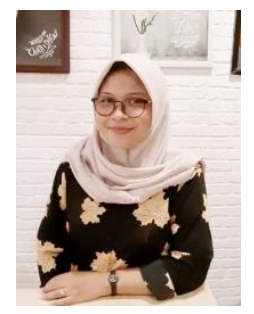

Fitroh Syuaidah Saryanto, prodi Administrasi Rumah Sakit, Fakultas Ilmu-Ilmu Kesehatan, Universitas Alma Ata.

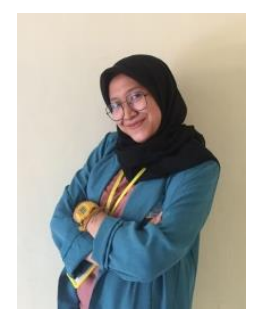

Dina Seftina, Ilmu Gizi, Fakultas Ilmu-Ilmu Kesehatan, Universitas Alma Ata.

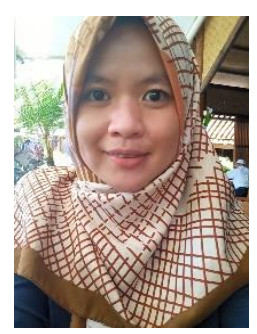

Fatma Siti Fatimah, Administrasi Rumah Sakit, Fakultas Ilmu-Ilmu Kesehatan, Universitas Alma Ata.

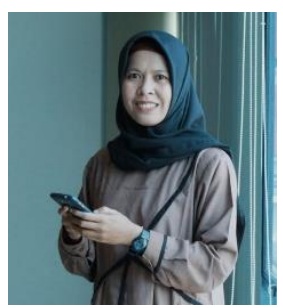

Nila Hidayah, Akuntansi, Universitas Alma Ata Yogyakarta. 